
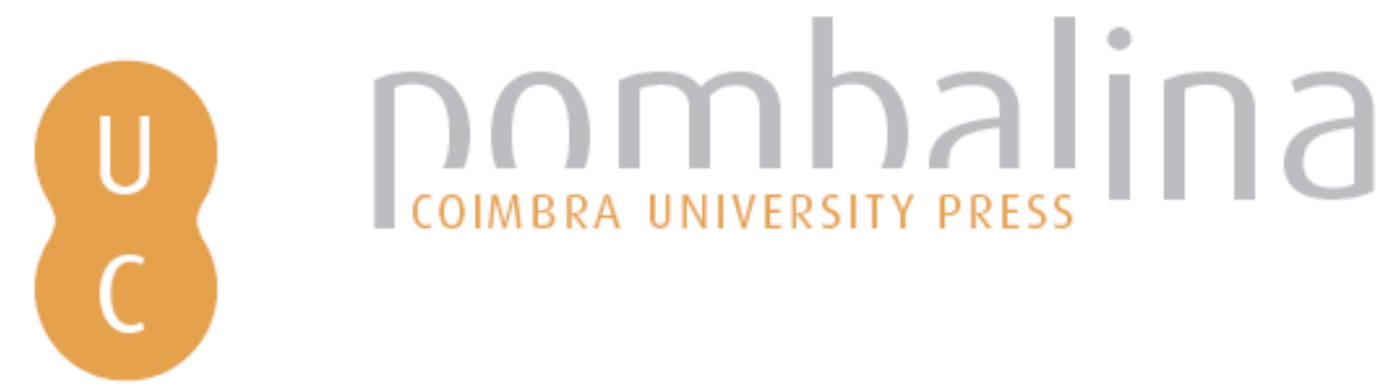

\title{
Setting government accounting standards: a comparative institutional analysis of China and The United States
}
Autor(es):
Chan, James; Yunxiao, Xu
Publicado por: Imprensa da Universidade de Coimbra
URL
persistente:
URI:http://hdl.handle.net/10316.2/32141
DOI:
DOI:http://dx.doi.org/10.14195/978-989-26-0422-0_4
Accessed : $\quad$ 26-Apr-2023 16:27:38

A navegação consulta e descarregamento dos títulos inseridos nas Bibliotecas Digitais UC Digitalis, UC Pombalina e UC Impactum, pressupõem a aceitação plena e sem reservas dos Termos e Condições de Uso destas Bibliotecas Digitais, disponíveis em https://digitalis.uc.pt/pt-pt/termos.

Conforme exposto nos referidos Termos e Condições de Uso, o descarregamento de títulos de acesso restrito requer uma licença válida de autorização devendo o utilizador aceder ao(s) documento(s) a partir de um endereço de IP da instituição detentora da supramencionada licença.

Ao utilizador é apenas permitido o descarregamento para uso pessoal, pelo que o emprego do(s) título(s) descarregado(s) para outro fim, designadamente comercial, carece de autorização do respetivo autor ou editor da obra.

Na medida em que todas as obras da UC Digitalis se encontram protegidas pelo Código do Direito de Autor e Direitos Conexos e demais legislação aplicável, toda a cópia, parcial ou total, deste documento, nos casos em que é legalmente admitida, deverá conter ou fazer-se acompanhar por este aviso.

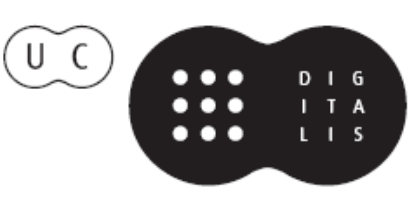




\section{Implementing Reforms in Public Sector Accounting}

Susana Jarge

Editor

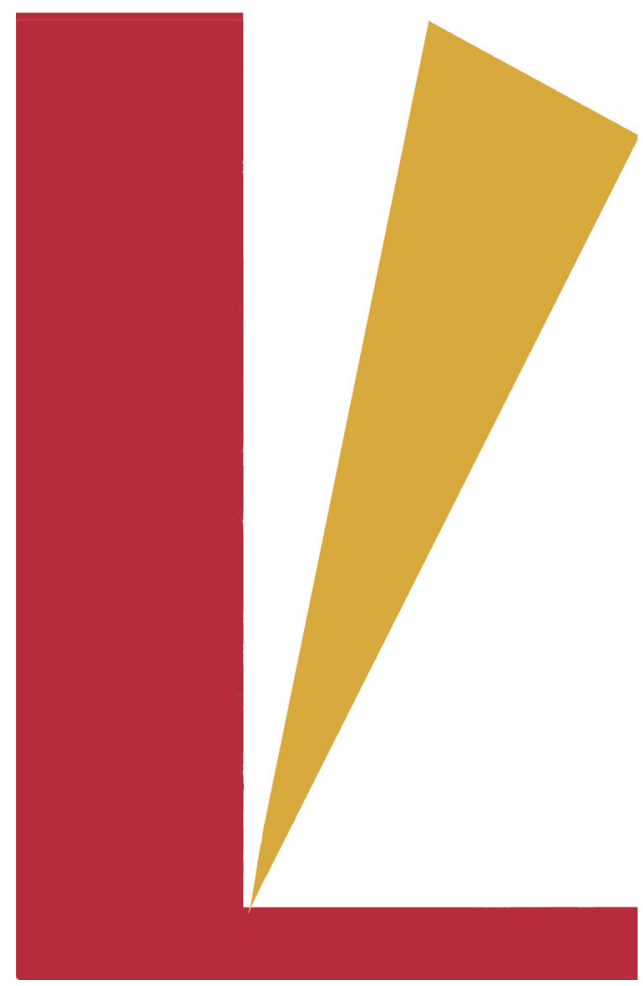


(Página deixada propositadamente em branco) 


\section{Implementing comparative Interational Reforms Governmental in Public Sector Accounting Accounting}

Susana Jorge Editor 
COORDENAÇÃO EDITORIAL

Imprensa da Universidade de Coimbra

Email: imprensauc@ci.uc.pt

URL: http://www.uc.pt/imprensa_uc

CONCEPÇÃO GRÁFICA

António Barros

\section{PAGINAÇÃO}

Simões \& Linhares, Lda.

\section{EXECUÇÃO GRÁFICA}

Simôes \& Linhares, Lda.

ISBN

978-989-8074-39-3

DEPÓSITO LEGAL

$281657 / 08$

\section{OBRA PUBLICADA COM O APOIO DE:}
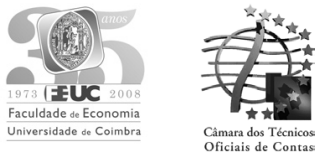

(C) Agosto 2008, IMPRENSA DA UNIVERSIDADE DE COIMBRA 
James Chan

Xu Yunxiao

\section{SETTING GOVERNMENT ACCOUNTING STANDARDS: A COMPARATIVE INSTITUTIONAL ANALYSIS OF CHINA AND THE UNITED STATES}

\section{Introduction}

Institutional analysis is a relatively neglected area of research in accounting, and comparative institutional analysis (CompIA) is an even more overlooked area within comparative international government accounting research (CIGAR). This is puzzling because institutions do matter in several important ways: they decide who sets accounting rules, how those rules are set, and how many rules are produced. It should be noted that we are using the term "institution" in the traditional sense of "organization" as in political institutions (Rhodes et al., 2006), instead of the "the rules of the game in a society... the humanly devised constraints that shape human interaction" as used in new institutional economics (North, 1990: 3-4; quoted in Aoki, 2001: 5).

Institutions tend to operate in the non-market sphere of society (e.g. political institutions) and devote to particular purposes (e.g. institutions of higher learning). This paper focuses on the organizations that have been created to set government accounting rules. These rules are variously called standards, principles, and regulations. They all serve to constrain the discretion of government accountants and auditors in order to promote greater uniformity and comparability in accounting and financial reporting. One might ask: Since governments already possess political autonomy and legal authority, why would they be willing to comply with the accounting rules set by someone else? Are some governments more willing than the others to do so? This paper will attempt to answer these questions by hypothesizing that countries with different political ideology and government structures would have dissimilar government accounting standard-setting institutions. We have chosen China and the United States for making this international comparison, since these countries are different politically in many ways.

This paper is structured as follows. Section 1 will sketch a theory that posits that the viability of government accounting standard-setting organizations depends on their ability to produce outputs to attract inputs from their stakeholders. This theory guides the description in Section 2 of the China Accounting Standards Committee (CASC), 
and the Federal Accounting Standards Advisory Board (FASAB) and Governmental Accounting Standards Board (GASB) in The United States. Section 3 will compare and contrast these organizations and attempt to explain their differences.

\section{A Theory of Government Accounting Standards Boards}

A government accounting standard-setting organization may be viewed in a system framework (Easton, 1966; Katz and Kahn, 1966). It uses a variety of inputs to produce outputs (Exhibit 1). These inputs include the political resources, economic resources, and intellectual resources identified in Exhibit 2. Its deliberation processes convert certain ideas into standards. If these standards are favorably received and are implemented by government accountants and enforced by auditors, they generate additional resources for another cycle of operations.

Exhibit 1 - A Standards Board as a System

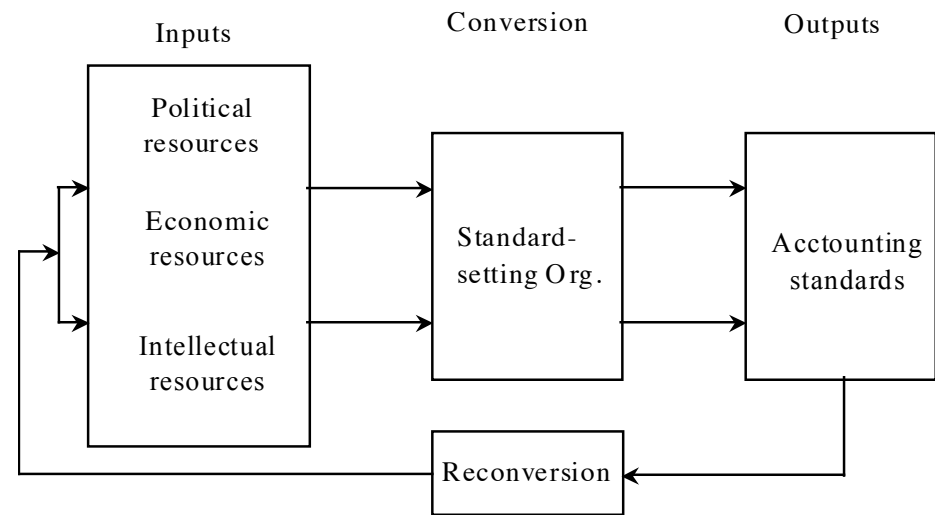

The systems approach identifies the crucial inputs that an organization needs to survive. It also emphasizes the critical importance of 'reconversion' - the process by which the products of standard-setting institutions motivate its stakeholders to continue to contribute their political, financial and intellectual resources so that it can operate as a going concern. As organization theorist Herbert Simon (1945) points out, these stakeholders must receive sufficient inducements to be willing to continue their contributions. We will therefore analyze the political, economic and social relationships in the context of government accounting and financial reporting, so that we can identify the types of contributions and inducements.

Using the concepts introduced in this section, the next section will describe the government accounting standard-setting organizations in China and the United States. 
Exhibit 2 - Elements of Institutional Analysis

\begin{tabular}{|c|c|}
\hline Systems Approach & $\begin{array}{c}\text { Institutional Analysis of } \\
\text { Government Accounting Standards Boards }\end{array}$ \\
\hline Political resources & $\begin{array}{l}\text { - Legal authority } \\
\text { - Professional authoritativeness } \\
\text { - Endorsement of influential persons }\end{array}$ \\
\hline Economic resources & $\begin{array}{l}\text { - Financial resources } \\
\text { - Human resources: members, staff and contributors to research and } \\
\text { technical activities } \\
\text { - Infrastructure and administrative support }\end{array}$ \\
\hline $\begin{array}{l}\text { Intellectual } \\
\text { resources }\end{array}$ & $\begin{array}{l}\text { - Contextual knowledge of responses to proposed standards } \\
\text { - Technical knowledge of the extent to which proposed standards meet } \\
\text { objectives }\end{array}$ \\
\hline Conversion & $\begin{array}{l}\text { - Research and technical activities to generate alternatives } \\
\text { - Deliberation of the merits of alternatives } \\
\text { - Due process of soliciting comments on alternatives } \\
\text { - Consensus formation and voting }\end{array}$ \\
\hline Outputs & $\begin{array}{l}\text { - Documents containing standards and related materials } \\
\text { - Practice guidance and educational materials }\end{array}$ \\
\hline Reconversion & $\begin{array}{l}\text { - Marketing of standards through public discourse } \\
\text { - Acceptance, endorsement of standards } \\
\text { - Use of standards in designing and modifying systems } \\
\text { - Use of standards in preparing financial reports } \\
\text { - Use of standards in auditing financial statements }\end{array}$ \\
\hline
\end{tabular}

\section{Institutional Profiles of Three Standards Boards}

The government accounting standard-setting bodies in China and the United States are, respectively, the China Accounting Standards Committee (CASC), and the Federal Accounting Standards Advisory Board (FASAB) and Governmental Accounting Standards Board (GASB). The following institutional profiles cover each board's mission, domain and authority, its financial and human resources, its standard-setting process, and activities and products.

\subsection{China Accounting Standards Committee (CASC)}

In China government accounting standard setting refers to the drafting of implementation regulations for the relevant statutes, namely the Budget Law (effective 1995) and the Accounting Law as amended (effective in 1985). Neither of these laws mentions "government accounting" as such, as this term was only recently introduced to China. Its closest analogy in China is general budget accounting used by the Ministry of Finance and provincial and local finance bureaus to monitor budget execution.

The authority of setting government accounting standards in China belongs exclusively to the Ministry of Finance, but the process has become more open and 
participatory in recent years. In the mid-1990s, the Budgeting Department in the Ministry of Finance undertook a project to revise budget accounting regulations, which are still in effect. In the spring of 2003, the China Accounting Standards Committee (CASC) was reorganized and expanded, and a group of advisors was appointed. The CASC now consists of three "professional committees" (the term is more accurately understood as "specialization committees") dealing with Accounting Theory, Accounting for Business Enterprises, and Accounting for Government and Nonprofit Organizations. The GNPAPC consists of a half dozen senior officials of the Ministry of Finance, National Audit Office and the State Tax Administration. It is assisted a 16-person advisory group, whose members serve two-year terms. They are drawn mostly from the Treasury, Budgeting and Accounting Regulation Departments in the Ministry of Finance itself, with additional representation of provincial finance bureaus, other Central Government departments and the academe.

The charter of the CASC makes clear that it is "under" the Ministry of Finance and "is the advisory body for setting Chinese accounting standards" (CASC, 2003: 3). The staff of the Ministry of Finance is responsible for drafting accounting standards for comments by the CASC. Since the adoption of the standards requires the administrative approval of the leadership group of the Ministry of Finance, this group in effect functions as the standardsetting body. The leadership group consists of the Minister, Vice Ministers and Assistant Ministers. Some of the Vice Ministers and Assistant Ministers oversee the departments that conduct research and develop government accounting standards: the Budgeting Department, the Accounting Regulation Department, and the Treasury Department. In each of these departments, there is a System Division whose staff actually does the necessary research and technical activities. To our knowledge, currently (Spring 2007), the Treasury Department takes the leading role in issuing guidance for government accounting system specifications, while the Accounting Regulation Department works on the conceptual issues related to government accounting standards.

The GNPAPC was structured to include the institutional interests both inside and outside of the Ministry of Finance. Within the Ministry of Finance, the scope of the Accounting Regulatory Department has been broadened to encompass government accounting, even though the department traditionally (and currently) is mainly concerned with business enterprise accounting. It therefore became necessary for the staff in the System Division of the department to acquire new knowledge in government accounting. By virtue of its cash management function, the Treasury Department in effect operates the government's expenditure accounting systems. A new position of Chief Accountant was created two years ago to emphasize the importance of the accounting function. Due to its operational function, the Treasury Department naturally tends to emphasize the practical aspects of government accounting. Ideally, these two departments' respective conceptual and practical orientations complement each other, but they may also complicate coordination. It is interesting to note that the Budget Department, which for many years was responsible for developing systems requirements for general budget accounting, is not directly represented on the CASC/ /GNPAPC. Its absence is puzzling, because an important function of a government's accounting system is to support and evaluate budget performance.

The representation of the State Tax Administration (STA) on the CASC/GNPAPC recognizes the importance of revenue in government finance, and the STA provides 
revenue data for the government financial management information system. The high-level representation of the National Audit Administration (NAA) is also noteworthy. The NAA recently created so-called "audit storms" in China by publicizing the results of its investigations into the frauds, waste and abuse in government. Weaknesses in accounting and financial control contributed, directly or indirectly, to the occurrence of these problems. So the NAA would clearly benefit from improvements in accounting systems.

The role of the CASC/GNPAPC is to provide guidance in standard setting and to comment and approve standards proposed by the staff of the Ministry of Ministry for submission to the leadership group of the ministry for final approval. The committee's contribution therefore lies in giving the Ministry of Finance an accurate assessment of the reception of the proposed standards by government departments. Its endorsement would increase the credibility of the proposed standards subject to the final approval of the leadership group of the Ministry of Finance. The high-level external participation may even increase the acceptance of the ministry's standards in government-wide implementation.

While the CASC/GNPAPC is advisory to the leadership group of the Ministry of Finance, the larger advisory group is intended to assist the professional staff of the Accounting Regulation Departments and the Treasury Department. This working advisory group includes senior staff members of relevant Central Government departments, provincial finance bureaus, and all the academics having a reputation in government accounting research. As each of these departments has only a handful of staff personnel working on government accounting matters, this working advisory group can provide the necessary technical assistance by doing background research. It is in this spirit that the CASC/GNPAPC commissioned, financed and published a collection of research reports. In this way, the dominance of the Ministry of Finance is balanced by a high degree of participation by other 'technocrats' and academics.

The work plan of the CASC indicated that government subsidies and other revenues would cover the expenses of research projects, various meetings and allowances for members of the committee. We are unable to estimate the amounts of financial resources devoted to government accounting standard setting in China. The activity is part-time, even for the professional staff of the Ministry of Finance. The commissioned research projects received only modest amounts of financial assistance, which do not adequately reflect the time and efforts devoted by the Ministry of Finance staff members, the members of the CASC/GNPAPC and of the advisory group. Unfortunately, we have no data to make an estimate of the time and effort.

The CASC has a four-stage process of setting accounting standards: initiating a new project, preparing an exposure draft, soliciting public comments, and releasing a standard. The Accounting Regulation Department is responsible for drafting standards. Specifically the System Division sets up a drafting team and invites others to participate as appropriate. The drafting process involves the preparation of discussion papers, exposure drafts, draft standards and draft standards for review.

In recognition of the substantial need for development and reform, a number of research projects were commissioned in 2004 and have been published (CASC, 2005). The monograph covers several major topics in government accounting: conceptual framework, financial reporting, structure of government accounting standards, and performance evaluation. 
Through visits, international conferences, and publications, the staff of the Ministry of Finance are quite familiar with the latest developments at the International Public Sector Accounting Standards (IPSAS) Board, in the United States and Europe. The applicability of accrual accounting to China has been explored (Lou, 2002b). China is now represented on the IPSAS Board. Virtually all the IPSAS, and American GASB and FASAB standards have been translated into Chinese. So are the Euro-CIGAR research report and the papers presented at the $9^{\text {th }}$ biennial CIGAR conference.

While considerable in-depth and comparative research has been done, to our knowledge, the Ministry of Finance has not (as of Spring 2007) approved a project to actually set government accounting standards.

\subsection{The American FASAB}

The Federal Accounting Standards Advisory Board (FASAB) is one of two government accounting standards boards in the United States. Its jurisdiction is limited to the United States Government (or the Federal Government) and its constituent units. The board is sponsored by the Secretary of the Treasury, the Director of the Office of Management, and the Comptroller General (head of the Government Accountability Office, the investigative arm of Congress). Its creation in late 1990 was a result of renewed emphasis on Federal financial management (Chan, 1994).

In the belief that "accounting and financial reporting standards are essential for public accountability and for an efficient and effective functioning of our democratic system of government," the FASAB was established "to develop accounting standards after considering the financial and budgetary information needs of congressional oversight groups, executive agencies, and the needs of other uses of Federal financial information" (FASAB Facts, 2006).

The domain of FASAB's standards covers only financial accounting and reporting. The Memorandum of Understanding (MOU) among the board's sponsors specifically provides: "The Board will consider [Federal] accounting concepts and standards. The Board will not set or propose budget concepts, standards, and principles. ..." (MOU, May 7, 2003).

The FASAB does not have legal authority of its own. "The Sponsors agree that [FASAB] standards ... are recognized to have substantial authoritative support, ... The Sponsors retain their authorities, separately and jointly, to establish and adopt accounting standards for the federal government" Therefore FASAB standards are submitted to the Sponsors for review. Among the Sponsors, the Comptroller General and the OMB Director has veto authority (MOU, May 7, 2003). Furthermore, capital accounting standards are subject to congressional review.

The membership of the FASAB and the professional status of the board's standards underwent significant change during the period between 2000 and 2003 in connection with the AICIPA's recognition of FASAB standards as Generally Accepted Accounting Principles (GAAP). In order to appreciate these changes, it is necessary to understand the changing environment of Federal financial reporting and auditing. Due to the requirements of audited financial statements in the 1990 Chief Financial Officers 
Act, Federal Agencies began engaging private-sector CPA firms to perform financial audits and render audit opinions.

Rule 203 of the AICPA's Code of Conduct requires CPAs to follow GAAP set by a board designated by the AICPA. By the time the FASAB was established, the AICPA had already designated the FASB in 1973 as the promulgator of GAAP for private-sector entities, and the GASB in 1986 for state and local governments. In order to receive the designation of a GAAP promulgator, a standard-setting body has to meet the criteria of independence, due process, domain and authority, human and financial resources, comprehensiveness and consistency. An AICPA task force assessed the FASAB against these criteria, and recommended changes in FASAB's Rules of Procedures and its charter -- the Memorandum of Understanding among its sponsors. Following the completion of the changes, the AICPA recognized the FASAB as promulgator of GAAP applicable to Federal Government entities.

Two major changes were made to increase the FASAB's independence. First, in terms of personnel, the initial October $1990 \mathrm{MOU}$ provided for a majority of six Federal government officials (three representing the sponsors, one CBO member; two representing Federal departments; three public members). The MOU was revised in 2002 to require a majority of six public members, resulting in $\mathrm{CBO}$ and the two department representatives losing their seats. This new composition went into effect on July 1, 2002. The MOU was revised in May 2003 to restore the CBO's seat on the FASAB, bringing the total membership to ten. Second, before the GAAP designation, FASAB recommended standards to its three sponsors. If the three principals agree to the standards and concepts, Comptroller General and the Director of OMB will publish them and announce them or their availability in the Federal Register (MOU October 1990). After the GAAP designation in October 1999, the current procedure of review and negative confirmation ("no objection") was instituted.

There are four main stakeholder groups that make up the FASAB organizational coalition (Exhibit 3). The first group consists mainly of FASAB's sponsors, who endow the FASAB with the delegated authority and financial resources. The benefits of their cooperative efforts result in Federal accounting and financial reporting standards for use in their respective functions as the Federal Government's financial policy maker (the $\mathrm{OMB}$ ), financial manager and accountant (the Treasury), and auditor and evaluator (the GAO). By giving the restructured FASAB Rule 203 designation, the AICPA enabled CPA firms to express audit opinions on the basis of GAAP. The second of stakeholders of FASAB are the 'producers' - FASAB board members, staff, as well as permanent and occasional task force participants. They contribute their technical knowledge as well as institutional knowledge about the Federal Government; in return they receive professional recognition and financial rewards. The third group of stakeholders of FASAB consists of the general and financial administrators of Federal Government units who are responsible for complying with the numerous finance-related laws and regulations. They and their staffs directly and indirectly contribute to FASAB's due process of producing a single set of uniform standards for all Federal entities. Their acceptance and implementation of FASAB's standards is their greatest contribution. Finally, the intended users of Federal Government financial reports - Congressional committees, civic groups and even the general public - contribute by their interest in and attention to the Federal Government's financial reports. Presumably, their needs are the ultimately reason why these reasons are produced and why there is a FASAB at all. 
Exhibit 3 - Stakeholders of the FASAB

\begin{tabular}{|c|c|c|}
\hline Stakeholders & Contribution & Inducement \\
\hline $\begin{array}{l}\text { Comptroller General, } \\
\text { Government Accountability } \\
\text { Office (GAO), whose Financial } \\
\text { Management and Assurance unit } \\
\text { conducts financial audits }\end{array}$ & \multirow{3}{*}{$\begin{array}{l}\text { delegation of authority, } \\
\text { acceptance of final FASAB } \\
\text { standards, general oversight, } \\
\text { partial funding, in-kind } \\
\text { support, making staff } \\
\text { resources available to } \\
\text { cooperate with FASAB }\end{array}$} & $\begin{array}{l}\text { standards for auditing Federal } \\
\text { entity financial statements; } \\
\text { the right to object and request } \\
\text { reconsideration of standards }\end{array}$ \\
\hline $\begin{array}{l}\text { Director, Office of Management } \\
\text { and Budget (OMB), which } \\
\text { includes the Office of Federal } \\
\text { Financial Management }\end{array}$ & & $\begin{array}{l}\text { standards for legal compliance, } \\
\text { monitoring resource } \\
\text { use, improving financial } \\
\text { management; right to object } \\
\text { and request reconsideration of } \\
\text { standards. }\end{array}$ \\
\hline $\begin{array}{l}\text { Secretary, Department of the } \\
\text { Treasury, which includes the } \\
\text { Financial Management Service } \\
\text { (FMS) }\end{array}$ & & $\begin{array}{l}\text { standards for government-wide } \\
\text { and agency accounting systems, } \\
\text { and for preparing financial } \\
\text { statements }\end{array}$ \\
\hline $\begin{array}{l}\text { Congressional Budget Office } \\
(\mathrm{CBO})\end{array}$ & $\begin{array}{l}\text { partial funding, } \\
\text { participation and support }\end{array}$ & $\begin{array}{l}\text { information for Congressional } \\
\text { decision making and oversight }\end{array}$ \\
\hline $\begin{array}{l}\text { American Institute of Certified } \\
\text { Public Accountants (AICPA) }\end{array}$ & $\begin{array}{l}\text { enhancing professional } \\
\text { authoritativeness of FASAB } \\
\text { standards by recognizing } \\
\text { them as GAAP }\end{array}$ & $\begin{array}{l}\text { ability of AICPA members to } \\
\text { invoke GAAP in expressing } \\
\text { audit opinions on financial } \\
\text { statements }\end{array}$ \\
\hline FASAB Members & $\begin{array}{l}\text { technical expertise and } \\
\text { institutional knowledge } \\
\text { about the Federal } \\
\text { environment; professional } \\
\text { credibility }\end{array}$ & $\begin{array}{l}\text { professional recognition, modest } \\
\text { financial compensation }\end{array}$ \\
\hline FASAB staff & $\begin{array}{l}\text { technical expertise and } \\
\text { ability to draft standards } \\
\text { and help build consensus }\end{array}$ & $\begin{array}{l}\text { compensation, career } \\
\text { advancement, professional } \\
\text { recognition }\end{array}$ \\
\hline $\begin{array}{l}\text { Members of Accounting and } \\
\text { Auditing Policy Committee } \\
\text { (AAPC) and other task forces }\end{array}$ & $\begin{array}{l}\text { technical expertise; } \\
\text { information about actual } \\
\text { practice, and perspectives } \\
\text { on feasibility of proposed } \\
\text { standards; donation of time }\end{array}$ & $\begin{array}{l}\text { opportunity to voice opinions; } \\
\text { feasible and better solutions to } \\
\text { practice problems }\end{array}$ \\
\hline $\begin{array}{l}\text { Federal agency management, } \\
\text { Chief Financial Officers, } \\
\text { Inspector Generals }\end{array}$ & $\begin{array}{l}\text { comments on exposure } \\
\text { drafts and other documents; } \\
\text { compliance with standards; } \\
\text { making staff resources } \\
\text { available for participation in } \\
\text { due process }\end{array}$ & $\begin{array}{l}\text { technical guidance for fulfilling } \\
\text { accounting and financial } \\
\text { reporting requirements; cost } \\
\text { savings that result from pooling } \\
\text { of talents and resources }\end{array}$ \\
\hline $\begin{array}{l}\text { Congressional committee, } \\
\text { especially oversight committees, } \\
\text { and authorizing and } \\
\text { appropriations committees }\end{array}$ & $\begin{array}{l}\text { attention to accounting, } \\
\text { financial management and } \\
\text { reporting issues; requests } \\
\text { for action and information; } \\
\text { general oversight }\end{array}$ & $\begin{array}{l}\text { more and better information } \\
\text { about agency financial status and } \\
\text { performance }\end{array}$ \\
\hline $\begin{array}{l}\text { Other users, including public } \\
\text { policy analysts in groups that } \\
\text { monitor Federal finances }\end{array}$ & $\begin{array}{l}\text { interest in and use of } \\
\text { financial reports to } \\
\text { improve policy analysis and } \\
\text { recommendations }\end{array}$ & $\begin{array}{l}\text { more and better information for } \\
\text { analyzing Federal Government } \\
\text { finances }\end{array}$ \\
\hline
\end{tabular}


The FASAB has access to substantial financial resources and human resources. However, the dollar figures below do not reflect the full cost incurred by its sponsors, nor the compliance costs of the Federal agencies. The FASAB's current funding (Fiscal Year 2007, beginning on October 1, 2006) is almost US\$2 million shared as follows: $\mathrm{OMB}$ and GAO each $27.5 \%$; $\mathrm{CBO}$ and Treasury each $22.5 \%$. In addition, the GAO provides the FASAB with office space, information technology support, and legal advices. (Executive Director of FASAB, email on October 30, 2006)

Supported by a full-time eight-person staff, headed by an executive director, currently (November 2006) the FASAB currently has ten board members, who serve on a part-time basis. Four board members represent the sponsors and the CBO. The board also includes six public or non-Federal members. The board's sponsors select them upon the recommendation of a panel convened by the chairman of FASAB, who is himself a public member.

FASAB has a standing task force called the Accounting and Auditing Policy Committee (AAPC), which was created in 1997 to provide guidance regarding the application of existing standards. This committee includes representatives from FASAB's three sponsors; three representatives from the Federal agency chief finance officers, who prepare agency financial statements; three representatives from the Federal agency Inspector Generals, who perform compliance audits and most agency financial audits; a FASAB member and, one member at large. In addition to the AAPC, the FASAB also appoints task forces on specific issues from time to time to receive expert views and recommended solutions. Task force members serve as part of their regular duties and receive no extra compensation.

The FASAB is subject to the provisions of the Federal Advisory Committee Act, including the requirement for open meetings. The board's rules of procedure are designed to meet the minimum requirements of the act, and include the following steps (FASAB Facts, 2006):

1. Identification of accounting issues and agenda decisions

2. Preliminary deliberations

3. Preparation of initial documents (issue papers and/or discussion memorandums)

4. Release of documents (e.g. exposure drafts) to the public, public hearings when necessary, and consideration of comments

5. Further deliberation and consideration of comments, and

6. Approval by at least a majority vote

7. Submission of proposed Statement to the Principals for ninety day review (forty five days for Interpretations)

8. Publication of final Statement or Interpretation

During the sixteen-year period (from October, 1990 to July 2007), the FASAB produced four Statements of Federal Financial Accounting Concepts, thirty-two Statements of Federal Financial Accounting Standards, seven Interpretations, six Technical Bulletins, six Technical Releases, and three Staff Implementation Guides. In addition, the due process has generated numerous exposure drafts, invitations for views, invitation to comment, preliminary views, and research reports. The board has also compiled two volumes of codifications: one with original statements and another with current text. All the FASAB's products are available free of charge from its website: www.fasab.gov, where a full list of documents can be found. 


\subsection{The American GASB}

The Governmental Accounting Standards Board (GASB) is the other American government accounting standards board. Created in 1984, its jurisdiction is limited to state and local government accounting and financial reporting. (Unless otherwise noted, the quotations are taken from the 2005-2006 edition of Facts about GASB and other publicly available sources available at the Board's website: www.gasb.org.)

The GASB regards its mission as "to establish and improve standards of state and local governmental accounting and financial reporting that will ... result in useful information for users of financial reports, and ... guide and education the public, including issuers, auditors and users of those financial reports."

This mission has been reaffirmed in the Board's strategic plan for 2005-2009, which stresses the Board's core values of independence, integrity, objectivity and transparency. The Board has also set specific goals and identified measurable outcomes in standard setting; constituent relations and communications; education; and organizational effectiveness.

Under the terms of agreement that established the GASB under the auspices of the Financial Accounting Foundation, the GASB will establish standards for activities and transactions of state and local governmental entities, and the FASB will establish standards for activities and transactions of all other entities. Although the issue of which board's standards should be followed by business enterprises and certain nonprofit organizations (e.g. hospitals, colleges and universities) has been dealt with, it continues to pose challenges for the scope and contents of GASB's standards.

The principal purpose of the GASB is to "issue Statements of Governmental Accounting Standards designed to improve financial reporting by state and local governments. It is also empowered by its Rules of Procedure to issue Statements of Governmental Accounting Concepts and Interpretations. The GASB staff is permitted to issue GASB Technical Bulletins and question-and-answer Special Reports.”

In 1984, the GASB succeeded the National Council on Governmental Accounting in setting accounting and financial reporting standards for state and local governments in the United States. In 1986, the American Institute of CPAs recognized the GASB's standards as generally accepted accounting principles (GAAP) for state and local governments. This means that, under the AICPA's Rules of Conduct for its members, CPAs have to justify departures from GASB standards when using those standards to assess the fair presentation of their audit clients.

The GASB does not have legal authority to require State and Local Government to adopt its standards. Rather, it relies on the endorsement of national groups that represent the political leaders, chief executives, government finance officers to persuade the legislatures of states and local governments to pass legislation to require compliance with GASB standards. The requirements of bond rating agencies of GAAP-based financial statements that have been independently audited also exerts considerable economic leverage on State and Local Governments. These and other interested in improving State and Local Government accounting and financial reporting (see Exhibit 4) were recruited to join the Governmental Accounting Standards Advisory Council (GASAC). While the formal function of the GASAC is to advice the GASB, GASAC members are expected to exercise their influence to promote the acceptance of GASB standards. 
Exhibit 4 - Organizations Represented on the GASAC

State and Local Governments, and Political/Management Leadership

("Public Interest Groups")

- National Conference of State Legislatures

- National Governors' Association

- National Association of Counties

- U.S. Conference of Mayors

- Council of State Governments

- National League of Cities

- International City/County Management Association

Preparers, Public Finance Professionals

- National Association of State Auditors, Comptrollers and Treasurers

- Government Finance Officers Association

- Native American Finance Officers Association

- National Association of Budget Officers

- Association of School Business Officials International

- National Association of College and University Business Officers

- National Association of State Retirement Administrators

- Healthcare Financial Management

- American Power Association

Private Sector Independent Auditors

- American Institute of Certified Public Accountants

Users of Financial Information

- Association of Finance Guarantee Insurers

- The Bond Market Association

- A bond rating agency

- Insurance Industry Investors

- National Federation of Municipal Analysts

- National Association of Bond Lawyers

Federal Government

- U.S. Government Accountability Office

- Governments Division, Bureau of the Census (at large member)

Allied Professional Associations

- American Accounting Association -- academics

- Association for Budgeting and Financial Management

- Association of Government Accountants

- Government Research Association 
The Governmental Accounting Standards Board (GASB) is a public - and private sector partnership of about thirty organizations. The degree of each organization's involvement with the GASB reflects the extent to which its professional, economic and political interests could be promoted or have to be protected. Four organizations were particularly instrumental in the creation of the GASB and continue to bear primary responsibility for its viability. The Financial Accounting Foundation (FAF) is a nonprofit organization created in 1973 to oversee and provide funding for the FASB, the only GAAP promulgated at the time. After the FASB failed in its bid to assume responsibility for setting GAAP for state and local government, the FAF's duty to preserve and protect the interest of the FASB led to its entry into the negotiation process for forming a GASB. After weighing the costs and benefits of these alternatives, the FAF decided to sponsor and fund the GASB. In the course of extended negotiations with the FAF, public sector representatives obtained the following favorable terms: (1) three public-sector representatives - including one nominated by the NASACT (National Association of State Auditors, Comptrollers and Treasurers) and another by the GFOA (Government Finance Officers Association) - would become member of the expanded FAF board of trustees; (2) the GASAC would have the authority to review and approve the nominations by the FAF trustees of members of the GASB, for which the GASAC took on the responsibility of assisting in raising funds for supporting the GASB (Chan, 1985).

The FAF provides the organizational infrastructure and oversight authority over the FASB. The NASACT, GFOA and the seven "public interest groups" possessed the political clout and legal authority over government accounting standards. A score of organizations jointed the GASAC; their contributions and incentives are also identified in Exhibit 5. With the AICPA's willingness to consider giving GAAP designation to GASB's standards - which it did two years later - the pieces fit together for the creation of the GASB as we know it now.

The GASB has been in operations now for 23 years. Since its seven board members are appointed or reappointed to five-year terms, the GASB current members now belong to the third generation of membership. Due to funding constraints, the board has remained part-time, with the exception of a full-time chairman. It appears that the 'psyche income' from personal satisfaction and professional recognition make up a substantial part of the members' inducements. The GASB usually holds public meetings at its headquarters in Norwalk, Connecticut on a monthly basis, supplemented by teleconferences and others means. It is in the nature of a part-time board with members scattered around the country to depend on the research and other support services of its full-time professional staff.

The GASB's procedures are designed to encourage broad public participation, and communication of all points of view and expressions of opinion. For many projects, the board appoints an advisory task force of outside experts, studies existing literature, and conducts or commissions such additional research, publishes a discussion document for public comments, conducts a public hearing and distributes an exposure draft. The board announces significant steps in the process and opens its meeting and meeting records to the public.

In addition to political support in the form of acceptance by the governmental institutions that do possess the direct legal authority to require certain types of government 
Exhibit 5 - Stakeholders of the GASB

\begin{tabular}{|c|c|c|}
\hline Stakeholders & Contribution & Inducement \\
\hline $\begin{array}{l}\text { Financial Accounting } \\
\text { Foundation (FAF) }\end{array}$ & $\begin{array}{l}\text { oversight, funding, appointment of GASB } \\
\text { members, resolution of jurisdictional } \\
\text { conflicts with FASB }\end{array}$ & $\begin{array}{l}\text { the ability to influence direction of } \\
\text { non-Federal government accounting } \\
\text { and reduce potential detriments to } \\
\text { FASB. }\end{array}$ \\
\hline $\begin{array}{l}\text { American Institute of Public } \\
\text { Accountants (AICPA) }\end{array}$ & $\begin{array}{l}\text { enhancing professional authoritativeness } \\
\text { of GASB standards by recognizing them } \\
\text { as GAAP }\end{array}$ & $\begin{array}{l}\text { the ability of AICPA members to } \\
\text { invoke GAAP in expressing audit } \\
\text { opinions }\end{array}$ \\
\hline $\begin{array}{l}\text { National Association of State } \\
\text { Auditors, Comptrollers and } \\
\text { Treasurers (NASACT) }\end{array}$ & $\begin{array}{l}\text { members' endorsement of the GASB and } \\
\text { its standards to state legislatures; willingness } \\
\text { to accept nation-wide standards, partial } \\
\text { funding support; participation in due } \\
\text { process }\end{array}$ & $\begin{array}{l}\text { availability to state governments } \\
\text { of uniform accounting standards } \\
\text { with a high level of professional } \\
\text { authoritativeness; a seat on the board } \\
\text { of trustees of the FAF }\end{array}$ \\
\hline $\begin{array}{l}\text { Government Finance Officers } \\
\text { Association (GFOA) }\end{array}$ & $\begin{array}{l}\text { members' endorsement of the GASB and } \\
\text { its standards to state and local governments; } \\
\text { acceptance of standards; partial funding } \\
\text { support; participation in due process }\end{array}$ & $\begin{array}{l}\text { availability to local and state } \\
\text { governments of uniform accounting } \\
\text { standards with a high level of } \\
\text { professional authoritativeness; a seat } \\
\text { on the board of trustees of the FAF }\end{array}$ \\
\hline GASB members & $\begin{array}{l}\text { technical expertise, contextual knowledge } \\
\text { about the environment of state and local } \\
\text { government financial reporting, professional } \\
\text { credibility }\end{array}$ & $\begin{array}{l}\text { professional recognition } \\
\text { and compensation }\end{array}$ \\
\hline GASB staff & $\begin{array}{l}\text { technical expertise and ability to draft } \\
\text { standards and help build consensus }\end{array}$ & $\begin{array}{l}\text { compensation and professional } \\
\text { recognition, career advancement }\end{array}$ \\
\hline Federal Government (GASAC) & $\begin{array}{l}\text { the Federal Government perspective, } \\
\text { interest in and endorsement of standard } \\
\text { setting process, }\end{array}$ & $\begin{array}{l}\text { more reliable information about } \\
\text { Federal grant programs; better } \\
\text { information for financial impact on } \\
\text { the Federal Government }\end{array}$ \\
\hline $\begin{array}{l}\text { State and Local Government } \\
\text { Legislators and Chief Executives } \\
\text { (GASAC) }\end{array}$ & $\begin{array}{l}\text { endorsement of GASB and its standards } \\
\text { to state and local government for } \\
\text { implementation, and approval of funding } \\
\text { support for the GASB }\end{array}$ & $\begin{array}{l}\text { enhanced credibility of government } \\
\text { financial reports, better information } \\
\text { for monitoring government financial } \\
\text { status and performance }\end{array}$ \\
\hline $\begin{array}{l}\text { Finance officials in individual } \\
\text { State and Local Governments } \\
\text { (represented by the GFOA on } \\
\text { GASAC) }\end{array}$ & $\begin{array}{l}\text { acceptance of standards, and seeking } \\
\text { funding and political support for } \\
\text { implementation }\end{array}$ & $\begin{array}{l}\text { readily availability of standards for } \\
\text { guiding development of accounting } \\
\text { systems; knowledge of standards } \\
\text { used by external auditors }\end{array}$ \\
\hline $\begin{array}{l}\text { CPA firms as auditors of } \\
\text { State and Local Government } \\
\text { (represented by the AICPA on } \\
\text { GASAC) }\end{array}$ & $\begin{array}{l}\text { acceptance and use of GAAP as basis for } \\
\text { expressing audit opinions }\end{array}$ & $\begin{array}{l}\text { availability of nation-wide standards } \\
\text { recognized by the AICPA for } \\
\text { expressing audit opinions }\end{array}$ \\
\hline $\begin{array}{l}\text { Capital market participants, } \\
\text { investors and creditors (GASAC) }\end{array}$ & $\begin{array}{l}\text { demand for accountability and use of } \\
\text { financial information, endorsement of } \\
\text { GAAP-based financial statements as a factor } \\
\text { in bond rating }\end{array}$ & $\begin{array}{l}\text { comparable financial information } \\
\text { for credit assessment, lower cost for } \\
\text { information analysis processing }\end{array}$ \\
\hline $\begin{array}{l}\text { Citizens and taxpayers advocacy } \\
\text { groups (GASAC) }\end{array}$ & $\begin{array}{l}\text { demand for accountability and use of } \\
\text { financial information }\end{array}$ & $\begin{array}{l}\text { information for assessing tax } \\
\text { and debt burden, lower cost for } \\
\text { information analysis }\end{array}$ \\
\hline $\begin{array}{l}\text { Public finance professionals } \\
\text { (GASAC) }\end{array}$ & $\begin{array}{l}\text { expertise and insight about the government } \\
\text { environment }\end{array}$ & $\begin{array}{l}\text { information for assessing impact on } \\
\text { professional fields or practice }\end{array}$ \\
\hline
\end{tabular}


accounting standards, the GASB also needs financial resources and human resources, which are inter-related to the extent that professional services have to be paid for.

In agreeing to sponsor the GASB, the FAF undertook the responsibility of funding the GASB. In 2005, the GASB generated $\$ 2$ million from subscription and publication sales, and $\$ 2.1$ million from contributions. The total revenue was sufficient to cover the direct expenses of approximately $\$ 3.7$ million of the board and research staff and advisory council, and another $\$ 0.3$ million in direct administrative expenses. However, the GASB could not meet its share of $\$ 1.5$ million of its common costs shared with the FASB.

Contributions to the GASB come from its 'constituent groups', including State and Local Governments, public accounting firms and individual practitioners, municipal securities industry investors/creditors, foundations and other organizations. In October 2006, the GASB launched a GASB support fee program directed at governments who benefit from the GASB in the sense that their auditors use GAAP set by the GASB to audit their financial statements. These governments are assessed a fee based on the dollar amount of Federal financial assistance; however payments are voluntary.

The GASB consists of a full-time chairman and six part-time members. It has a fulltime professional staff of ten persons, and shares administrative support services with the FASB. The GASB has access to the GASAC for strategic advice and to task forces for technical advice. The GASB's main activities involve the research and deliberation for setting standards, including the development of a conceptual framework. Equally important are the 'outreach' activities in the due process of soliciting and considering the views of various constituencies on all accounting and financial reporting issues. Much time and resources are spent on developing consensus in the hope of increasing acceptance of the board's products.

The GASB's primary products are its Statements of Governmental Accounting Standards (51 since its formation to July 2007), and Statements of Governmental Concepts (four during the same period). In addition the Board issues Interpretations to clarify, explain or elaborate on existing GASB standards or NCGA standards. The GASB staff issues technical bulletins and special reports to give implementation guidance for the board's standards. The board's due process also generates various discussion, memoranda, invitations to comment, preliminary views, and exposure drafts. The GASB's substantive products are for sale in part to generate revenues to support its operations.

\section{Comparative Summary}

Since the United States has two government accounting standards boards, we compare them before making a Sino-American comparison. 


\subsection{A FASAB-GASB Comparison}

Exhibit 6 identifies the similarities and differences between the FASAB and GASB in terms of organizational attributes.

Exhibit 6 - A Comparative Summary of the FASAB and GASB

\begin{tabular}{|c|c|c|}
\hline \multicolumn{3}{|l|}{ Common Features } \\
\hline \multicolumn{3}{|c|}{$\begin{array}{l}\text { - AICPA recognizes the standards of both GASB and FASAB as GAAP. } \\
\text { - Both boards focus on financial accounting and external general purpose reporting. } \\
\text { - Both boards use extensive due process procedures in setting standards. } \\
\text { - Both boards are essentially part-time, with full-time staff support and extensive use of task forces. }\end{array}$} \\
\hline \multicolumn{3}{|l|}{ Dissimilarities } \\
\hline & GASB & FASAB \\
\hline $\begin{array}{l}\text { Number of } \\
\text { Governments to which } \\
\text { standards are applicable }\end{array}$ & $\begin{array}{l}50 \text { state governments and } 87,000 \\
\text { local governments }\end{array}$ & $\begin{array}{l}\text { One government -- the United } \\
\text { States (or Federal) Government }\end{array}$ \\
\hline Domain of Standards & $\begin{array}{l}\text { state and local government } \\
\text { accounting and financial } \\
\text { reporting }\end{array}$ & $\begin{array}{l}\text { Accounting and financial reporting } \\
\text { of the Federal Government as a } \\
\text { whole and component units }\end{array}$ \\
\hline $\begin{array}{l}\text { Sponsorship and } \\
\text { Oversight }\end{array}$ & $\begin{array}{l}\text { A private-sector nonprofit } \\
\text { foundation, in association with } \\
\text { an advisory council with private- } \\
\text { and public-sector membership }\end{array}$ & $\begin{array}{l}\text { OMB Director, Treasury Secretary } \\
\text { and Comptroller General }\end{array}$ \\
\hline Legal Authority & $\begin{array}{l}\text { No direct legal authority, } \\
\text { relying on groups representing } \\
\text { government officials to endorse } \\
\text { GASB and its standards to } \\
\text { legislative and oversight bodies }\end{array}$ & $\begin{array}{l}\text { OMB Director, Treasury Secretary } \\
\text { and Comptroller General reserve } \\
\text { legal authority, but agree to adopt } \\
\text { FASAB standard developed through } \\
\text { agreed-upon procedure }\end{array}$ \\
\hline Funding & $\begin{array}{l}\text { Contributions and sale of } \\
\text { publications }\end{array}$ & $\begin{array}{l}\text { Jointly by the three sponsors and } \\
\text { the CBO }\end{array}$ \\
\hline $\begin{array}{l}\text { Dissemination of } \\
\text { standards }\end{array}$ & $\begin{array}{l}\text { Pronouncements for sale and } \\
\text { subscription, other documents } \\
\text { available from the GASB's } \\
\text { website. }\end{array}$ & $\begin{array}{l}\text { All documents available for } \\
\text { download from FASAB's website } \\
\text { free of charge }\end{array}$ \\
\hline
\end{tabular}




\subsection{A Chinese-American Comparison}

Exhibit 7 identifies the similarities between the CASC and the FASAB/GASB.

Exhibit 7 - A Sino-American Comparison

\begin{tabular}{|c|c|c|}
\hline \multicolumn{3}{|l|}{ Common Features } \\
\hline \multicolumn{3}{|c|}{$\begin{array}{l}\text { The CASC/GNPAPC, FASAB and GASB } \\
\text { - All do not have legal authority themselves, and are advisory in nature. } \\
\text { - Are all essentially part-time, with full-time staff support and extensive use of task forces. }\end{array}$} \\
\hline \multicolumn{3}{|l|}{ Dissimilarities } \\
\hline & CASC/GNPAPC & FASAB/GASB \\
\hline Number of standards boards & $\begin{array}{l}\text { One government accounting } \\
\text { standards board for the whole } \\
\text { country }\end{array}$ & $\begin{array}{l}\text { Two government accounting } \\
\text { standards boards }\end{array}$ \\
\hline $\begin{array}{l}\text { Governments to which } \\
\text { standards are applicable }\end{array}$ & $\begin{array}{l}\text { The Central Government, as } \\
\text { well as all provincial and local } \\
\text { governments. }\end{array}$ & $\begin{array}{l}\text { FASAB for the Federal Government, } \\
\text { and GASB for state governments } \\
\text { and local governments }\end{array}$ \\
\hline Domain of Standards & $\begin{array}{l}\text { No clear delineation of } \\
\text { external financial reporting, } \\
\text { but accounting standards are } \\
\text { distinguished from accounting } \\
\text { systems requirements. }\end{array}$ & $\begin{array}{l}\text { Form and contents of financial } \\
\text { reports (including financial } \\
\text { statements) intended for external } \\
\text { users. }\end{array}$ \\
\hline Sponsorship and Oversight & $\begin{array}{l}\text { The administrative leadership of } \\
\text { the Ministry of Finance }\end{array}$ & $\begin{array}{l}\text { FASAB: A troika of top legislative } \\
\text { and executive fiscal officers; } \\
\text { GASB: a private and public-sector } \\
\text { partnership }\end{array}$ \\
\hline Legal Authority & $\begin{array}{l}\text { CASB/GNPAPC has no legal } \\
\text { authority; it provides advice } \\
\text { to the Accounting Regulation } \\
\text { Department; the leadership of } \\
\text { the Ministry of Finance has } \\
\text { the administrative authority } \\
\text { to set government accounting } \\
\text { standards. }\end{array}$ & $\begin{array}{l}\text { FASAB and GASB themselves have } \\
\text { no legal authority. } \\
\text { FASAB: legal authority rests with } \\
\text { the sponsors. } \\
\text { GASB: legal authority rests with } \\
\text { the state and local governments' } \\
\text { legislature to require use of GASB } \\
\text { standards }\end{array}$ \\
\hline Enforcement & $\begin{array}{l}\text { Administrative authority of the } \\
\text { Ministry of Finance; the next } \\
\text { level of administrative authority } \\
\text { belongs to the State Council. } \\
\text { Should financial statement audits } \\
\text { be conducted, statutory authority } \\
\text { exists in the Audit Law. }\end{array}$ & $\begin{array}{l}\text { FASAB: auditing required by } \\
\text { statutes and administrative } \\
\text { requirements; not enforceable on } \\
\text { the legislative and judicial branches. } \\
\text { GASB: auditing by government } \\
\text { and private-sector certified public } \\
\text { accountants (CPAs) }\end{array}$ \\
\hline Funding & $\begin{array}{l}\text { Provided by the Ministry of } \\
\text { Finance from its appropriations }\end{array}$ & $\begin{array}{l}\text { FASAB: cost-sharing by the } \\
\text { sponsors and the CBO; } \\
\text { GASB: contributions and } \\
\text { publication sales revenue. }\end{array}$ \\
\hline Dissemination of standards & No standards issued to date. & $\begin{array}{l}\text { FASAB: Free download from the } \\
\text { Internet. } \\
\text { GASB: Subscription and sale }\end{array}$ \\
\hline
\end{tabular}




\subsection{Explaining the Sino-American Differences}

Based on the descriptive institutional profiles in Section 2 and the above comparative analyses, we would characterize the institutional arrangements for setting government accounting standards in China and the United States as:

- Type 1: Public - and private - sector partnership with a professional orientation - the American GASB during the entire period of its existence, and the American FASAB since its 2003 reorganization.

- Type 2: Public - and private - sector partnership with a governmental orientation - the American FASAB prior to its 2003 reorganization.

- Type 3: Government monopoly with administrative dominance - the CASC/ /GNPPC under the Ministry of Finance in China.

These differences in institutional attributes may be explained by the nature of the government system and the relationship between the accounting/auditing profession and government.

That China has one government accounting standards board while the United States has two boards is directly attributed to the relationship between the national government and sub-national governments. China is a unitary state with a powerful Central Government (Saich, 2001). As such, the Central Government makes all the important policy decisions for implementation by provincial and local governments. Every ministry and commission at the Central Government has subordinate counterparts at the provincial and local levels. This hierarchical structure is maintained uniformly throughout the country even in the face of considerable regional disparity in economic and social conditions. In other words, the Central Government creates and oversees the organizational infrastructure for making public policies, including those governing public budgeting and financial management. In contrast, the United States has a federal system. The Federal Government has only those powers that the Constitution of the United States expressly gives to it, with all the powers reserved for the States and the people. Specifically, the Federal Government has its own budgeting and financial management system, with many features that are not replicated in State and local governments. Each of the States has its own autonomy fiscal systems covering such areas as taxation, budgeting, accounting, auditing and treasury management. American local governments are the creatures of a State, which ultimately supervises their financial affairs, even though home rule is granted to larger local governments. State and local governments are obliged to comply with the budgeting and financial management requirements of Federal grants. However, they resisted a proposal under which the Federal Government would create and fund an organization to set accounting standards for State and local governments. In short, the fundamental difference in constitutional arrangement between levels of government goes a long way to explain the basic structural differences between China and United States in 'who is in charge' of setting government accounting standards.

The extent of centralization of fiscal authority explains the differences in the sponsorship and oversight mechanism for the government accounting standards boards in China and the United States. In China, the Ministry of Finance, which is responsible for making fiscal policy, possesses virtually all the administrative authority in the area 
of budgeting and financial management (Lou, 2002a). The Budgeting Department in the Ministry prepares (and executes) the Central Government budget, and combines it with the aggregation of provincial government budgets to form the national budget. The Treasury Department manages the government's cash flows and is in effect in charge of the accounting system. The Accounting Regulation Department is assigned the administrative jurisdiction over the drafting of the more conceptual accounting standards for both public and private sectors, and serves as the secretariat of the China Accounting Standards Committee. While the National Audit Administration is independent of the ministries, the Auditor General reports to the Prime Minister, rather than to the National People's Congress - the Chinese parliament. Thus administrative dominance is an appropriate characterization of the Chinese fiscal system. In contrast, in the American Federal Government, Congress and the executive branch share fiscal authority. The Congressional 'watchdog' Government Accountability Office (GAO) audits all aspects of executive departments' performance: finance, compliance, as well as economy, efficiency and economy. Prior to the formation of the FASAB, as an extension of congressional fiscal oversight, the GAO had played a preeminent role in setting accounting rules and approving accounting systems. The Office of Management and Budget, part of the Executive Office of the President, sets budget policy and financial management policy, among other functions. The Treasury Department's Financial Management Service (FMS), in coordination with departmental counterparts, operates the central accounting, reporting and cash management functions. This explains why the FASAB is sponsored, funded and overseen by a consortium of three officials representative both the Executive and Legislative branches of Government.

The extent of involvement of private sector accountants and auditors in government accounting and auditing is another major difference between China and the United States. The Chinese CPAs, whose professional association is regulated by the Accounting Regulation Department of the Ministry of Finance, are not engaged to audit any government units. That is the exclusive authority of the National Audit Administration (NAA). However, even as the NAA conducts many legal compliance audits, it does not perform financial statements audits, for the simple reason that Chinese Government at all levels do not currently produce business-type financial statements (i.e., balance sheets, statement of activities or operations). Instead the Finance Minister and his provincial and local counterparts present (unaudited) summary final accounts to legislatures at various levels of government. In contrast, American private sector ('independent') auditors represented by the American Institute of Certified Public Accountants (AICPA) have a long tradition of involvement in public sector fiscal affairs, to the point that they audit the annual financial statements of many state and local governments, and some Federal Government departments. The use of private-sector CPAs to enhance the credibility of government financial reports gives the AICPA, which designates the promulgators of American Generally Accepted Accounting Principles (GAAP) considerable leverage in influencing the governance of the GASB and the FASAB.

In both China and the United States, the legal authority to set government accounting standards (in the generic sense of rules, and not only Generally Accepted Accounting Principles) rests with the relevant government officials. However, for different reasons, these officials have found it useful to create advisory bodies, which enjoy varying degrees 
of independence and influence. Comparatively, the CASC is the least independent and influential. In the United States, in an effort to gain AICPA's designation of FASAB as a GAAP promulgator, the FASAB was given more independence by reversing the ratio of Federal and public members, and greater authority in releasing standards. The GASB has the highest degree of independence and influence for several reasons: (a) the GASB operates outside of the jurisdiction of any State and Local Government; (b) the large number and diversity of sponsors and overseers of the GASB reduces the power of any one of them; (c) the backing of the bond rating agencies gives the GASB considerable leverage. (Beginning in the 1970s, bond rating agencies have required State and Local Government borrowers to publish audited financial statements prepared on the basis of GAAP; otherwise, bond ratings would be adversely affected.)

\section{Conclusion}

The above discussion of the extensive differences should not be pushed too far. The seeming incomparability of the Chinese and American institutional structures for setting government accounting standards raises a basic question of "what are government accounting standards"? In the contemporary American context, the term refers to the standards set by the FASAB and GASB that are recognized by the AICPA as GAAP and used by public - and private - sector auditors in assessing government financial statements. These GAAP operate parallel with rules and regulations set by the fiscal officers (e.g. state comptrollers or auditors) for their own jurisdictions. In the Federal Government, the FASAB standards have replaced the GAO's own accounting rules, and serve as the conceptual foundation of the detailed accounting regulations used by the Treasury Department's Financial Management Service (FMS). In each State, the State comptroller issues accounting regulations for the State Government as well as Local Governments in the State. In the Chinese context, private sector auditors are not involved in auditing the government, and the government does not produce annual financial statements for the National Audit Administration to attest to. So the current accounting systems regulations are analogous - not to GASB and FASAB standards - but to administrative regulations.

Finally, all accounting standard-setting organizations are coalitions of stakeholders. Some organizational coalitions are more fragile than the others, i.e. susceptible to the withdrawal or threat of withdrawal of critical stakeholders. In this regard, the GASB is most financially fragile in most part because its revenues depends on the contributions of organizations of State and Local Governments officials. (Recently the president of the GFOA has advocated transferring the function of the GASB to the FASB.) The FASAB is politically fragile because it crucially depends on the sponsorship of the $\mathrm{OMB}$, Treasury and the GAO. (The recent disagreement between the 'public' and 'federal' members of FASAB on Social Security issues has given rise to anxiety about the board's future.) The existence and utilization of the CASC/GNPAPC depends on the leadership group of the Ministry of Finance for its existence, work program and direction.

In conclusion, government accounting standard-setting organizations are institutions of accountability (see Dowdle, 2006 for a general discussion of public accountability). 
The American FASAB and GASB and the Chinese CASC/GNPAPC each emphasizes a different kind of accountability. Before its reorganization in 2003, the FASAB reflected an emphasis on the accountability of the executive branch to the legislative branch, being concerned with the separation of power and checks and balances. Afterwards, the FASAB shifted the emphasis to the government's public accountability. The GASB's accountability structure is eclectic, mixing political accountability of the government to the public, as well its accountability to creditors and investors in government securities. The Chinese CASC/GNPAPC's emphasis is on administrative accountability, especially the oversight function of the Ministry of Finance.

It has often been said that 'institutions matter'. The existence of standard-setting organizations is a necessary but insufficient condition for the development of government accounting standards. The Chinese Ministry of Finance has created the institutional structure and has invested substantial amounts of resources in building the capacity to set government accounting standards. However, in the absence of internal and external demands for government accounting standards (as versus system requirements), the potential of the CASC/GNPAPC has not been realized. In contrast, statutory requirements (on the Federal Government) and bond rating agency demands on behalf of the capital market (on state and local governments) have driven the development of a large number of American government accounting - and financial reporting - standards.

\section{References}

Aoki, Masahiko (2001), Toward a Comparative Institutional Analysis, Cambridge, Massachusetts: MIT Press.

Chan, James L. (1985), The Birth of the Governmental Accounting Standards Board: How? Why? What Next? Research in Governmental and Nonprofit Accounting, Vol. 1, 3-32.

Chan, James L. (1994), Accounting and Financial Management Reform in the United States Government: An Application of Professor Luder's Contingency Model, in Perspectives on Performance Measurement and Public Sector Accounting, edited by Ernst Buschor and Kuno Schedler, Bern, Switzerland: Paul Haupt Publishers, 17-41.

Dowdle, Michael W. (ed.) (2006), Public Accountability: Designs, Dilemmas and Experiences, Cambridge, England: University of Cambridge Press.

Easton, David (1966), A Framework for Political Analysis, Englewood Cliffs, New Jersey: Prentice Hall.

FASAB - Federal Accounting Standards Advisory Board (2006a), Facts about the FASAB.

FASAB (2006b), Memorandum of Understanding Among the General Accounting Office, The Department of the Treasury, and the Office of Management and Budget on Federal Government Accounting Standards and a Federal Accounting Standards Advisory Board (October 1990; September 1999; May 2003) and First Amendment, July.

FASAB (2004), Statement of Responsibilities and Characteristics of Members of the Federal Accounting Standards Advisory Board. Rules of Procedures (updated April).

FASAB (2000), FASAB Begins Changes Resulting from AICPA Rule 203 Designation, January-March

FASAB (1999), The AICPA Council Designates FASAB as a 'Rule 203' Body, October.

GASB - Governmental Accounting Standards Board, Facts about the GASB (2005-2006).

GASB, 2006 Members

Governmental Accounting Standards Advisory Council, 2006 Members. 
Statement of Budgeted Revenues and Expenses for the Year ending December 31, 2006.

GASB's Rules of Procedure.

The Structure for Establishing Governmental Accounting Standards: Report of the Committee to Review Structure for Governmental Accounting Standards of the FAF and GASAC (January 26, 1989).

Katz, Daniel and Robert L. Kahn (1966), The Social Psychology of Organizations, New York: John Wiley, "Organizations and the System Concept," 14-29.

North, Douglas (1990), Institutions, Institutional Change and Economic Performance, Cambridge, England: Cambridge University Press.

Rhodes, R. A. W.; Binder, Sarah A. and Rockman, Bert A. (eds.) (2006), The Oxford Handbook of Political Institutions, Oxford, England: University of Oxford Press.

Simon, Herbert A. (1945), Administrative Behavior, New York: The Free Press.

Saich, Tony (2001), Governance and Politics of China, England: Palgrave.

\section{Chinese Language Publications:}

Lou, Jiwei (ed.) (2002a), Chinese Government Budgeting: System, Management and Cases, Beijing: China Finance and Economics Publishing House.

Lou, Jiwei (ed.) (2002b), The Future of [Chinese] Government Budgeting and Accounting: An Overview and Inquiry into Accrual Reforms, Beijing: China Finance and Economics Publishing House.

People's Republic of China, Ministry of Finance, China Accounting Standards Committee (CASC) (2003), About the China Accounting Standards Committee.

People's Republic of China, Ministry of Finance, China Accounting Standards Committee (CASC) (2005), ed. Government Performance Evaluation and Government Accounting, Dalian Publishing House. 


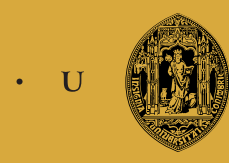

C - 